\title{
Lifelong learning and the Sustainable Development Goals (SDGs): Probing the implications and the effects
}

\author{
Leona M. English ${ }^{1} \cdot$ Arne Carlsen $^{2}$
}

Published online: 1 April 2019

(c) UNESCO Institute for Lifelong Learning and Springer Nature B.V. 2019

This special issue came out of a think tank meeting hosted by the UNESCO Institute for Lifelong Learning (UIL) in September 2016. Global experts convened to examine the Sustainable Development Goals (SDGs) in light of lifelong learning, and to investigate the possibilities and limits of education as an enabler of sustainability and development. The starting place, both then and in this issue, was the 2030 Agenda for Sustainable Development, in which the United Nations (UN) deliberately recognises the integral role of lifelong learning in ensuring sustainable development (UN 2015a). ${ }^{1}$ Among the 17 Sustainable Development Goals named in the Agenda, SDG 4, with its corresponding 10 targets, calls on Member States to "ensure inclusive and equitable quality education and promote lifelong learning opportunities for all" (UN 2016). ${ }^{2}$ But lifelong learning is also viewed as critical for the attainment of many other SDGs, such as gender equality (SDG 5); decent work and economic growth (SDG 8); health and well-being (SDG 3); responsible consumption and production (SDG 12); and climate change mitigation (SDG 13).

Yet, the importance of lifelong learning is not a new idea, as various global goalsetting exercises over the years have drawn attention to lifelong learning as integral to development. Previous agendas such as Education for All (EFA) (WEF 2000) ${ }^{3}$

\footnotetext{
1 UN (United Nations) (2015a). Transforming our world: The 2030 Agenda for sustainable development. New York: United Nations. Retrieved 25 February 2019 from https://sustainabledevelopment.un.org/ post2015/transformingourworld.

${ }^{2}$ UN (2016). Sustainable Development Goal 4: Targets and indicators [dedicated webpage]. New York: UN. Retrieved 8 November 2018 from https://sustainabledevelopment.un.org/sdg4\#targets.

3 WEF (World Education Forum) (2000). The Dakar framework for action. Education for all: Meeting our collective commitments. Paris: UNESCO. Retrieved 31 January 2018 from: http://unesdoc.unesc o.org/images/0012/001211/121147e.pdf.
}

Leona M. English

lenglish@stfx.ca

Arne Carlsen

carlsenarne@gmail.com

1 Department of Adult Education, St. Francis Xavier University, Antigonish, Canada

2 Department of Education, Zhejiang University, Hangzhou, China 
and the Millennium Development Goals (MDGs) (UN 2015b), ${ }^{4}$ for instance, already foreshadowed the present agenda of the Sustainable Development Goals and called attention to the need for a lifelong learning approach in addressing social and environmental issues. In 2015, the United Nations Educational, Scientific and Cultural Organization (UNESCO) followed the UN in identifying lifelong learning as an integral part of its own new agenda, the Education 2030 Framework for Action (FFA), and has worked to promote lifelong learning as an integral part of the SDGs. The United Nations 2030 Agenda increases the number of goals, from 8 in the Millennium Development Goals (MDGs) set for 2000-2015 to 17 SDGs for the next 15-year period, and deliberately designates education as one specific development goal (UN 2015a). It expands the focus from schooling to lifelong learning, making adult education and higher education as well as technical education part of the spectrum embraced by the international community in the achievement of sustainability (Benavot 2017). ${ }^{5}$

Yet, naming SDG 4 as a specific education goal took a great deal of planning and negotiation. There was an intense two-year consultation process involving stakeholders and Member States in shaping the future education agenda; this consultation culminated in the World Education Forum (WEF) which convened in Incheon, Republic of Korea, in May 2015. The Forum's outcome document, Education 2030 (UNESCO 2016), encompasses both the Incheon Declaration and the above-mentioned Education 2030 Framework for Action (FFA), the purpose of which is to help in the implementation of SDG 4 . With its 10 specific targets, the education goal addresses objectives to be met by 2030. Global indicators have been determined as well, to measure progress in all countries, with due attention given to cultural and national variances. The Incheon Declaration signals the international community's commitment to SDG 4, and tasks UNESCO to provide guidance and leadership to the education goal (UNESCO 2016). ${ }^{6}$

The UNESCO Institute for Lifelong Learning (UIL) has long been engaged with the agenda of lifelong learning across the lifespan through its many programmes to support literacy, policy development, adult learning and education. Its early interest in lifelong learning is vindicated by two seminal reports, Learning to be: The World of Education Today and Tomorrow (Faure et al. 1972) ${ }^{7}$ and Learning: The Treasure

\footnotetext{
${ }^{4}$ UN (2015b). The Millennium Development Goals report 2015. New York: UN. Retrieved 8 November 2018 from http://www.undp.org/content/dam/undp/library/MDG/english/UNDP_MDG_Report_2015. pdf.

${ }^{5}$ Benavot, A. (2017). Education for people, prosperity and planet: Can we meet the sustainability challenges? Editorial, special issue. European Journal of Education, 52(4), 399-403.

${ }^{6}$ UNESCO (United Nations Educational, Scientific and Cultural Organization). (2016). Incheon declaration and Framework for action for the implementation of Sustainable Development Goal 4. Towards inclusive and equitable quality education and lifelong learning opportunities for all. Education 2030. Paris: UNESCO. Retrieved 25 February 2019 from https://unesdoc.unesco.org/ark:/48223/pf00002456 56.

${ }^{7}$ Faure, E., Herrera, F., Kaddoura, A.R., Lopes, H., Petrovsky, A.V., Rahnema, M. \& Ward, F.C. (1972). Learning to be: The world of education today and tomorrow. Paris: UNESCO. Retrieved 30 April 2018 from http://unesdoc.unesco.org/images/0000/000018/001801e.pdf.
} 
Within (Delors et al. 1996). ${ }^{8}$ As the only organisational unit in the UN family that holds a global mandate for lifelong learning, UIL categorises and collates national lifelong learning policies and strategies, conducts international research on lifelong learning, and supports nation states in their efforts to foster learning. The institute's online Collection of Lifelong Learning Policies and Strategies, for instance, presents a unique effort to provide leadership on this important front. ${ }^{9}$ Another platform for discussion is UIL's publication series on lifelong learning policies and strategies. ${ }^{10}$

The articles featured in this special issue of the International Review of Education - Journal of Lifelong Learning (IRE) support the role of lifelong learning in the Sustainable Development Goals and take the process one step further to examine the ways in which lifelong learning is conceptualised, enacted and monitored in the 21 st century. This special issue provides a forum for examination and gives space to policy and practice, which are central to UIL's promotion of policy dialogue and the enabling of strategic action, in particular on the development and implementation of SDG 4 and its 10 targets. The contributions look closely at the intersection of education and development, and the implicit acknowledgement that education is integral to the achievement of several of the SDGs in addressing poverty, inequality, social development and economic growth.

Clearly, there is a need for supporting lifelong learning issues, given some of the global issues we are facing at the end of this decade and indeed in this millennium, such as displacement of populations, illiteracy, economic inequity, and a need for new qualifications and skills. Contributors to this issue theorise and analyse their understanding of lifelong learning in light of the increasing global emphasis on measuring implicit links between development and areas such as education (SDG 4), health (SDG 3) and gender (SDG 5). The primacy of lifelong learning in the achievement of these goals is underscored by the recognition in the SDGs of lifelong learning as the master concept for education policies and as the organising principle of education. Based on the renewed focus on lifelong learning at the global level, this special issue of IRE analyses and interprets the 2030 Agenda in terms of the meaning and implications of lifelong learning for all for a full and abundant life.

The authors challenge existing notions of lifelong learning and argue for its benefits beyond education and learning. At the core of their discussions are the ways in which governments and policymakers understand and implement lifelong learning in various contexts. The importance of this exercise is underscored by Member States' call for assistance with addressing the SDGs and for updating and formulating their own lifelong learning agenda and policy action for 2030.

\footnotetext{
8 J. Delors et al. (1996). Learning: The treasure within. Report to UNESCO of the International Commission on Education for the Twenty-First Century. Paris: UNESCO.

9 To visit the database, go to http://uil.unesco.org/lifelong-learning/lifelong-learning-policies [accessed 25 February 2019].

10 So far, five volumes have been published in the series. The latest one, published in 2018, is Promoting lifelong learning for all: The experiences of Ethiopia, Kenya, Namibia, Rwanda and the United Republic of Tanzania. It was edited by Daniele Vieira do Nascimento and Raúl Valdés-Cotera. For more information, visit http://uil.unesco.org/publications [accessed 25 February 2019].
} 
As guest editors, we are very much aware that, over time, this journal has given a great deal of attention to conceptualising lifelong learning. An earlier special issue on the future of lifelong learning (Carlsen and Haddad 2013) ${ }^{11}$ is a case in point. The present special issue draws on those earlier discussions and responds to the current need for workable lifelong learning policies and strategies in light of the United Nations 2030 Agenda. It is our hope that practitioners, researchers and policymakers will be aided through this current dialogue in moving forward with the fulfilment of SDG 4 and other goals.

The authors, international researchers and policy specialists, were chosen for their expertise in various areas of lifelong learning. Their articles help to further the dialogue on the 2030 Agenda and the SDGs, and deepen our thinking and practice of lifelong learning, as well as contributing to the ongoing discourse on development and education in the 21 st century. This special issue strengthens this journal's contribution to international efforts in lifelong learning.

Yet, as editors and authors, we are aware of many gaps that we could not possibly fill. For instance, a glaring omission is attention to the role of popular education and informal learning, which are components of a full lifelong learning platform. Popular education has long been the central venue for lifelong learning in many countries, not only in the Global South, but in spaces where civil society is most threatened. This could be explored in future, not least in relation to SDG target 4.7, which strives to ensure that by 2030 ,

all learners acquire the knowledge and skills needed to promote sustainable development, including, among others, through education for sustainable development and sustainable lifestyles, human rights, gender equality, promotion of a culture of peace and non-violence, global citizenship and appreciation of cultural diversity and of culture's contribution to sustainable development (UN 2016).

To complement this special issue, we recommend that its readers learn from distinguished scholar activists Shirley Walters and Astrid Von Kotze (Walters and von Kotze 2018) ${ }^{12}$ who have published their insights on popular education and lifelong learning in the noted journal Studies in the Education of Adults.

This special issue features five articles, each one emphasising a different aspect of lifelong learning and its links to the SDGs. We begin with two articles which draw on the Recommendation on Adult Learning and Education as a basis for their analysis (UNESCO 2015) ${ }^{13}$.

The first article, "Lifelong learning challenges: Responding to migration and the Sustainable Development Goals" is by Leona English and Peter Mayo. It focuses

\footnotetext{
11 Carlsen, A., \& Haddad, G. (Eds) (2013). The future of lifelong learning. Special issue. International Review of Education, 59 (3), entire special issue.

12 Walters, S., \& von Kotze, A. (2018). "If you can't measure it, it doesn't exist"? Popular education in the shadows of global reporting on adult learning and education. Studies in the Education of Adults. https ://doi.org/10.1080/02660830.2018.1522052.

13 UNESCO (2015). Recommendation on adult learning and education (2015). Paris/Hamburg: UNESCO/UIL. Retrieved 29 March 2019 from https://unesdoc.unesco.org/ark:/48223/pf0000245179.
} 
on migration, one of the largest issues affecting many countries worldwide, both in terms of migration between countries and within countries. Irrespective of whether they are migrants, refugees or temporary workers, people on the move are highly vulnerable and in need of a lifelong learning response to enable them to develop and live full and productive lives. English and Mayo argue for processes that address the "disposability" (Bauman 2006, p. 40) ${ }^{14}$ and precarity of migrants. They critique the neo-liberal impulses that undergird resistance to inclusion, and offer the possibility of genuine inclusion into receiving countries.

Andreas Fejes continues this theme in his article entitled "Adult education and the fostering of asylum seekers as 'full' citizens" by looking at asylum seekers in his own country of Sweden, arguing that adult education is required to help these displaced persons become full participants in Swedish democracy. In making his argument, Fejes ably draws on Foucauldian theory to analyse policy reports as well as interviews with project managers and study circle leaders who are involved with the government programme Svenska från dag ett [Swedish from Day One], which is designed to help asylum seekers learn the language and integrate themselves into Swedish society. The Foucauldian lens allows Fejes to look critically at the effects of this seemingly benign programme, which may in fact position the asylum seeker as less than a full citizen in this receiving country. Fejes' critique allows the reader to think about programming in more complex ways.

The third article, entitled "Examining the application of the lifelong learning principle to the literacy target in the fourth Sustainable Development Goal (SDG 4)", also looks at language and assumptions about literacy and numeracy. Ulrike Hanemann focuses especially on the literacy and numeracy target 4.6 of SDG 4 to determine the extent to which it reflects the lifelong learning perspective guiding UNESCO's Education 2030 Framework for Action (FFA). The target envisages a minimum proficiency level equivalent to levels achieved at successful completion of basic education. Building on her many years of experience as a programme specialist at UIL, Hanemann utilises a framework that unpacks "lifelong literacy" and discerns three closely interrelated dimensions, namely (1) literacy as a lifelong learning process; (2) literacy as a life-wide process; and (3) literacy as a part of sector-wide reforms to foster lifelong learning systems. Having analysed this target, she argues that an expanded vision of literacy has not yet taken hold. She concludes that there is still a long way to go before literacy (and numeracy) are tackled from a lifelong learning perspective, which would potentially have a transformative effect on the achievement of the SDGs.

Ellen Boeren's article, entitled "Understanding Sustainable Development Goal (SDG) 4 on 'quality education' from micro, meso and macro perspectives", brings to the fore the global educational policy focus on analysing achievement through the narrow lens of indicators, benchmarks and targets. Like Hanemann, Boeren resists narrow and limited frameworks being used to measure growth and achievement. Employing structure and agency theory, she examines the 10 targets that comprise

\footnotetext{
14 Bauman, Z. (2006). The crisis of the human waste disposal industry. In D. Macedo \& P. Gounari (Eds), Globalization of racism (pp. 36-40). Boulder, CO: Paradigm.
} 
SDG 4 from a range of micro, meso and macro perspectives. By breaking the targets down, she demonstrates that reaching indicators, benchmarks or targets - the dominant approach in current global education policy making - is a rather complex task. Boeren's analysis reveals that a stronger approach is needed, one in which there is shared responsibility for the achievement of SDG 4 among individuals, education and training institutions and regulating governments in UN Member States, with the challenge being how to effect this model.

Kjell Rubenson too is concerned with the issue of measurement. In his article entitled "Assessing the status of lifelong learning: Issues with composite indexes and surveys on participation", he draws attention to the increasing global concern for exact measurement of lifelong learning. Rubenson reviews the two leading surveys on adult education and learning, the Organisation for Economic Co-operation and Development (OECD)'s Programme for the International Assessment of Adult Competencies (PIAAC) and the European Union's Adult Education Survey (AES), as well as the defunct Canadian Composite Learning Index (CLI). He asks critical questions of whether lifelong learning or learning for work (i.e. the skills agenda) are actually being measured in these assessments, and he raises issues such as lack of clarity around terms and the absence of context in these measurements. He argues that the narrow boundaries around the indicators used in assessing lifelong learning need to be broadened so that nations can have a clearer understanding and picture of lifelong learning and suggests UIL might take the lead in putting this into practice.

In sum, these five articles raise critical issues concerning the achievement of the SDGs, especially SDG 4. The contributing authors offer caution in how education is identified and measured in various contexts, including in local, national and international arenas. While lifelong learning remains a bona fide goal, the articles in this issue encourage us to continue to raise questions about how lifelong learning is understood, how it is enacted and how it is measured. In becoming a commonplace term, and positioned at the core of new strategies to respond to our rapidly changing world, lifelong learning runs the risk of losing its sharp edge and its potential to transform our world. We harness it to tackling industrial disruption, addressing new socio-economic developments in relation to the fourth industrial revolution with automation, artificial intelligence and big data, ${ }^{15}$ and supporting transversal skills development and social cohesion. In the next decade, as the international community focuses on the SDGs, we would do well to sharpen our critical thinking capacity and to continue with our scrutiny, providing sound research to support promotion of lifelong learning opportunities for all.

\footnotetext{
15 Klaus Schwab, the founder of the World Economic Forum, provides a helpful typology in which the First Industrial Revolution is characterised as employing water and stream for mass production. The Second Industrial Revolution used electric power, the Third used information technology, and the Fourth uses a fusion of technological, physical and biological forces for production. Schwab's point is that progress is now moving at breakneck speed and is uncontrolled. See Schwab, K. (2017). The fourth industrial revolution. New York: Crown Publishing.
} 
Publisher's Note Springer Nature remains neutral with regard to jurisdictional claims in published maps and institutional affiliations.

Leona M. English is Professor of Adult Education at St. Francis Xavier University, Canada. She received the Houle Award for Outstanding Literature in Adult Education from the American Association for Adult and Continuing Education in 2013, and again in 2016, for her books Learning with Adults: A Critical Pedagogical Introduction (with Peter Mayo; Sense Publishers 2012) and Feminism in Community: Adult Education for Transformation (with Catherine J. Irving; Sense Publishers 2015). She has served as president of the Canadian Association for the Study of Adult Education and general editor of the International Encyclopedia of Adult Education (Palgrave Macmillan 2005), and is presently co-editor of the Adult Education Quarterly journal. In 2015, she was inducted into the International Adult and Continuing Education Hall of Fame. From 2015 to 2016, she held the position of Head of Publications at the UNESCO Institute for Lifelong Learning (UIL), where she is also an Honorary Fellow.

Arne Carlsen is currently Chair Professor at Zhejiang University, China. He has served variously as Secretary-General of the Nordic Folk High School Council, Rector of the Nordic Folk Academy (Sweden), Vice-rector for Education at the Danish University of Education, and National Coordinator of a number of international comparative assessments of student achievement in reading, mathematics and citizenship education, namely the Progress in International Reading Literacy Study (PIRLS), the Trends in International Mathematics and Science Study (TIMMS) and the International Civic and Citizenship Education Study (ICCS). He was Founding Chair of the Asia-Europe Meeting (ASEM) Education and Research Hub for Lifelong Learning, Executive Director of the International Alliance of Leading Education Institutes (IALEI), and Chair of the university consortium that managed the Erasmus Mundus Joint European Master's Programme in Lifelong Learning: Policy and Management. He was inducted into the International Adult and Continuing Education Hall of Fame in 2017, and holds a number of honorary doctoral degrees and professorships. From 2011-2017, he held the position of Director of the UNESCO Institute for Lifelong Learning (UIL). 